\title{
PEMBARUAN PEMIKIRAN PENDIDIKAN ISLAM MUHAMMAD BASIUNI IMRAN (1906-1976 M)
}

\author{
Nasrullah \\ Ahmad M. Sewang \\ Syamsudduha \\ Nurman Said \\ Institut Agama Islam Sultan Muhammad Syafiuddin \\ nasrh.006@gmail.com
}

\begin{abstract}
Abstrak: Penelitian ini bertujuan untuk mengetahui pembaruan pemikiran Pendidikan Islam Muhammad Basiuni Imran tahun 1906 sampai 1976. Tahun 1906 adalah tahun ia mulai mengajar di sekolah Sultaniyah. Tahun 1909 ia melanjutkan pendidikan ke Mesir dengan tujuan al-Azhar. Pada saat itulah ia mengenal pembaruan pemikiran pendidikan Islam Muhammad Rasyid Rida. Tahun 1913 ia pulang ke Sambas dan dilantik menjadi Maharaja Imam. Tahun 1916 menjadi guru di Madrasah al-Sultaniyah. Tahun 1918 ditunjuk menjadi pengawas pada sekolah yang sama. Tahun 1936 mendirikan sekolah Tarbiyatul Islam. Tahun 1963 mendirikan sekolah Kulliyatul Muballighin.

Penelitian ini menggunakan metode șejarah dengan pendekatan sosiologi, antropologi, prosopografi dan sejarah intelektual. Teori yang digunakan adalah teori pembaruan dan perubahan sosial. Penelitian ini juga menggunakan dua kajian yaitu pustaka dan lapangan. Kajian pustaka untuk melacak pemikiran pembaruan melalui karya-karyanya yang banyak. Sementara kajian lapangan melihat praktek pembaruan yang dilakukan Muhammad Basiuni Imran.

Penelitian ini menunjukkan bahwa pada tahun 1906 Muhammad Basiuni Imran memotivasi para siswa akan pentingnya pendidikan. Pendidikan bagi Muhammad Basiuni Imran adalah kunci utama untuk meraih kemajuan. Tahun 1916 ketika ia diangkat menjadi guru pada Madrasah al-Sultaniyah, ia berhasil mengintegrasikan kurikulum agama dan umum secara bertahap dan perlahan dan berlanjut pada sekolah Tarbiyatul Islam tahun 1936. Pada sekolah yang kedua yaitu sekolah Tarbiyatul Islam ia juga berhasil mengenalkan sekaligus menerapkan ko-edukasi dan manajemen sekolah berbasis administrasi. Upaya yang dilakukannya tersebut melawan arus.
\end{abstract}

\section{PENDAHULUAN}

Sosok Muhammad Basiuni Imran bagi masyarakat Sambas adalah ulama yang berkontribusi besar terhadap kemajuan kehidupan keagamaan. Banyak hal yang telah ia sumbangkan bagi masyarakat Sambas. Diantaranya adalah mereformasi kelembagaan ulama, mendirikan baitul mal, mendirikan sekolah Tarbiyatul Islam, mendirikan sekolah Kulliyatul Muballigin dan lain sebagainya. Upaya yang dilakukannya tersebut tidak lepas dari pengaruh gurunya Muhammad Rasyid Rida ketika ia belajar di Mesir tahun 1909.

Muhammad Basiuni Imran belajar di Mesir selama empat tahun sampai 1913. ${ }^{1}$ Sejak belajar di Mesir itulah ia bertekad membawa ide-ide pembaharuan gurunya dan ternyata memberikan sentuhan warna yang tersendiri dalam kehidupan keagamaan masyarakat di Kesultanan Sambas. ${ }^{2}$ Sambas dikenal dengan sebutan Serambi Makkah

\footnotetext{
${ }^{1}$ Risa, Perkembangan Islam di Kesultanan Sambas; Kajian Atas Lembaga Keislaman Pada Masa Pemerintahan Sultan Muhammad Syafiuddin II Tahun 1866-1922 M(Yogyakarta: Ombak, 2016), h. 94.

${ }^{2}$ Urai Reza Fahmi, Selayang pandang Kerajaan Islam Sambas (Sambas: Istana Alwatzikhoebillah Sambas, 2008), h. 39. Sultan Muhammad Syafiuddin II dalam kebijakan pemerintahnya lebih menitikberatkan pada masalah pendidikan guna membangun kesejahteraan rakyat.
} 
tidak hanya karena masyarakatnya taat beribadah, melainkan juga sebagai pusat pendidikan keagamaan baik yang didirikan oleh Sultan Muhammad Syafiuddin II (1866-1923) dengan lembaga pendidikan al-Sultaniyah ${ }^{3}$ pada tahun 1916 yang merupakan madrasah tertua di Kalimantan ${ }^{4}$ maupun yang dirintis oleh Muhammad Basiuni Imran sendiri yaitu Tarbiyatul Islam tahun 1934.

Kepergian Muhammad Basiuni Imran ke Tanah suci Mekah sekaligus menuntut ilmu disana pada tahun 1901 memang pada dasarnya adalah atas perintah Sultan Muhammad Syafiuddin II namun hal tersebut adalah atas saran dan masukan dari Khatib H. Muhammad Djabir. ${ }^{6}$ H. Muhammad Djabir ini menjabat sebagai khatib selain bertugas sebagai penyampai dakwah di sekitar pusat kesultanan juga termasuk dalam jajaran penasehat sultan. Atas kedudukannya itulah ia diperkenankan menyampaikan saran atau gagasan yang sifatnya tidak mengganggu kedudukan sultan. H. Muhammad Djabir menilai sosok yang tepat untuk dikirim belajar ke Mekah adalah Muhammad Basiuni Imran yang tidak lain adalah keponakannya sendiri.

Sejak awal sebelum ia belajar ke Mekah, Muhammad Basiuni Imran sudah menampakkan kecerdasan dan keseriusannya dalam menuntut ilmu terlebih lagi ketika ia di Mekah dan di Mesir. Dua kota inilah yang nantinya mengilhami Muhammad Basiuni Imran untuk mengajukan sebuah pertanyaan yang terlihat sederhana tapi mempunyai makna yang cukup mendalam kepada gurunya Syeikh Rasyid Riḍa melalui majalah al-Manār. Pertanyaan itulah yang pada akhirnya membuat namanya terkenal di dunia Islam sekaligus mengangkat nama Kesultanan Islam Sambas tahun 1929.

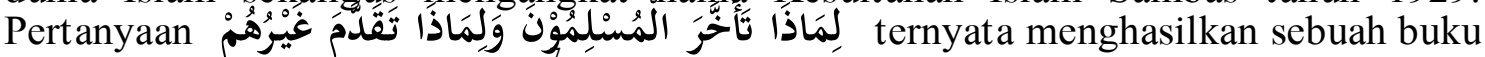
yang fenomenal di dunia Islam. Kiprah dan sepak terjang Muhammad Basiuni Imran sebagai Qadhi dan Mufti di Kesultanan Sambas tahun $1913^{8}$ mulai dikenal.

Pertanyaan di atas bukan spontanitas yang dilontarkan Muhammad Basiuni Imran kepada gurunya, melainkan dari perenungan yang cukup panjang ketika ia melihat negara lain yaitu Mekah dan Mesir yang cukup berkembang baik dari segi infrastruktur, teknologi maupun pendidikan. Ia bandingkan dengan kehidupan masyarakat muslim di kerajaan yang jauh dari nilai kemoderenan. Kemudian ia melihat realitas umat Islam di negerinya seperti orang asing di negeri sendiri lantaran fasilitas mendapatkan pendidikan dan ekonomi sangat kontras dengan kehidupan non muslim terutama masyarakat China mendapat layanan yang sangat istimewa dari pihak Belanda.

Muhammad Basiuni Imran yang mendapat jabatan Qadhi dan Mufti di kerajaan Islam Sambas sangat gigih memajukan Islam. Ia terus mendorong Sultan Muhammad Syafiuddin II mendirikan lembaga pendidikan sebagai wadah mencerdaskan kehidupan umat. Hal tersebut sangat beralasan karena untuk mengimbangi peran sekolah-sekolah yang didirikan oleh kolonial Belanda. Sekolahsekolah yang didirikan tersebut adalah mempunyai maksud yang tidak lain sebagai misionaris atau menanamkan ajaran kristen. Sampai tahun 1916, Pemerintah Belanda

\footnotetext{
${ }^{3}$ Erwin Mahrus, Membangun Pendidikan; Gagasan Pendidikan Maharaja Imam Sambas Basiuni Imran 1885-1976 (Pontianak: Yayasan Leluhur Nusantara, 2003), h. 69.

${ }^{4}$ H. A. Mustafa, dkk., Sejarah Pendidikan Islam di Indonesia (Bandung: CV. Pustaka Setia, 1998), h. 93.

${ }^{5}$ Erwin Mahrus, Falsafah dan Gerakan Pendidikan Islam Maharaja Imam Sambas Muhammad Basiuni Imran (Pontianak: STAIN Press, 2007), h. 4.

${ }^{6}$ Sunandar, "Peran Maharaja Imam Muhammad Basiuni Imran dalam Kehidupan Sosial Keagamaan Masyarakat Kerajaan al-Watzkhoebillah Sambas 1913-1976", Tesis (Yogyakarta: Pascasarjana Konsentrasi Agama dan Filsafat, UIN Sunan Kalijaga, 2012), h. 97.

${ }^{7}$ Pertanyaan di atas ditujukan langsung oleh Muhammad Basiuni Imran kepada Rasyid Ridha. Namun karena kesibukannya, ia pun meminta kepada Amir Syakib Arselan, seorang ulama terkenal Timur Tengah ketika itu untuk menjawab pertanyaan tersebut sehingga menghasilkan sebuah buku yang fenomenal.

${ }^{8}$ Erwin Mahrus, Falsafah dan Gerakan Pendidikan Islam, h. 5.
} 
telah mendirikan sekolah di antaranya adalah Sekolah Rendah tahun 1902, Sekolah Bumiputera Kelas II tahun 1903, Byzondere School tahun 1910 dan Hollands Chineesche tahun $1915 .{ }^{9}$

Perhatian Muhammad Basiuni Imran terhadap upaya memajukan Islam khususnya pendidikan Islam ditunjukkannya dengan mengelola Madrasah alSultaniyah, ${ }^{10}$ sebuah lembaga pendidikan yang dibiayai oleh Sultan Muhammad Syafiuddin II tahun 1916. Isi kurikulum madrasah yang muatannya adalah materi keagamaan diserahkan Sultan sepenuhnya kepada Muhammad Basiuni Imran untuk disesuaikan dengan kondisi umat Islam Sambas. ${ }^{11}$ Polesan materi keagamaan ini membuat masyarakat Sambas menyebut madrasah dengan sebutan "sekolah Arab". Madrasah al-Sultaniyah ini tetap berjalan dalam pemerintahan Sultan-Sultan penggantinya. Baru di tahun $1935^{12}$ dirasakan kebutuhan untuk mendirikan sekolah yang mengajarkan ilmu pengetahuan umum di samping ilmu agama dengan organisasi seperti halnya sekolah model Barat. Sekolah ini diberi nama sekolah Tarbiyatul Islam. Perubahan ini kemudian berdampak pada perubahan sistem kelembagaan, metodologi dan kurikulum sekolah. Kebijakan ini antara lain tampak dari pengembangan kurikulum pendidikannya yaitu pelajaran agama dan umum diajarkan bersama-sama.

Pendidikan yang dikembangkan oleh Basiuni Imran tidak hanya menitikberatkan pada aspek moral dan keagamaan, tetapi juga memberikan kepada peserta didiknya pengetahuan dan keterampilan yang bersifat umum dengan tujuan membentuk kaum terdidik yang di samping memiliki pengetahuan agama yang cukup juga memiliki pengetahuan dan keterampilan. Pembaruan Islam di atas dilakukannya dengan hati-hati. Ia tetap menginginkan ciri Islam menjadi landasan bagi sebuah lembaga pendidikan, meski pada aspek tertentu ia bersikap terbuka terhadap pengaruh luar dengan menerapkan kurikulum pendidikan Belanda pada sekolah yang ia dirikan. ${ }^{14}$

\section{KAJIAN TEORI}

\section{A. Pembaruan Pemikiran Pendidikan Islam}

Istilah pembaruan dalam Islam menurut Khoiriyah adalah dilatarbelakangi oleh semakin merebaknya kalangan Islam tradisi yang memegang teguh bahasa agama dan budaya lokal yang keberadaannya dianggap dapat mengancam keberadaan Islam itu sendiri. Inti ajaran purifikasi adalah kembalinya pemahaman agama berdasarkan landasan normatif, yaitu al-Qur'an dan al-Hadits dari berbagai model interpretasi dan pelaku keagamaan bercorak lokal di luar ajaran normatif. ${ }^{15}$ Selain itu Pemahaman pembaruan juga tidak menolak nilai-nilai kemoderenan. Dengan kata lain dalam hal ibadah merujuk kepada al-Qur'an dan sunnah Rasul serta amalan sahabat, sedangkan dalam hal mu'amalah menyesuaikan dengan kemajuan perkembangan zaman atau dalam bahasa agama disebut shā lih li kulli zamān wa makānn. Gerakan pembaruan yang dimaksudkan disini adalah selain menyeru masyarakat agar kembali kepada ajaran Islam yang sesungguhnya sesuai dengan tuntunan Rasulullah juga mengakomodir kemajuan ilmu pengetahuan. Menurut Geertz sebagaimana yang dikutip oleh Syafiq A. Mughni, gerakan yang semacam inilah yang disebut dengan Puritik Islam yang merupakan ciri dari gerakan modern di Indnonesia. ${ }^{16}$

\footnotetext{
${ }^{9}$ Ansar Rahman, Kabupaten Sambas; Sejarah Kesultanan dan Pemerintahan Daerah (Sambas: Dinas Pariwisata Pemkab Sambas, 2001), h. 78.

${ }^{10}$ Erwin Mahrus, Falsafah dan Gerakan Pendidikan Islam, h. 6.

${ }^{11}$ Erwin Mahrus, Falsafah dan Gerakan Pendidikan Islam, h. 5.

${ }^{12}$ Erwin Mahrus, Falsafah dan Gerakan Pendidikan Islam, h. 5.

${ }^{13}$ Erwin Mahrus, Falsafah dan Gerakan Pendidikan Islam, h. 6.

${ }^{14}$ Erwin Mahrus, Falsafah dan Gerakan Pendidikan Islam, h. 6.

${ }^{15}$ Khoiriyah, Islam dan Logika Modern, Mengupas Pemahaman Pembaruan Islam (Yogyakarta: Ar-Ruzz Media Group, 2008), h. 20 - 21.

${ }^{16}$ Syafiq A. Mughni, Hassan Bandung Pemikiran Islam Radikal, (Surabaya: Bina Ilmu, 1994), h. 7 .
} 
Suatu gerakan keagamaan apapun namanya, dalam prakteknya tidak mungkin muncul secara tiba-tiba tanpa ada peristiwa atau penjelasan yang melatarbelakanginya. Menurut Imam Tholkhah dan Abdul Azis sebagaimana yang dikutip oleh Nuhrison M. Nuh dan Zaenal Abidin, menjelaskan tentang tumbuhnya organisasi keagamaan disebabkan oleh adanya aliran atau gerakan yang berhasil bertahan dan malah berkembang baik di suatu daerah dan kemudian dipandang sebagai gerakan utama di wilayah tersebut. ${ }^{17}$

Teori gerakan keagamaan menurut Kuntowijoyo adalah berawal dari kekecewaan atau ketidakpuasan suatu masyarakat atau kelompok tertentu terhadap dominasi masyarakat yang lain dalam menjalankan kehidupan keagamaan. Ia memberikan contoh munculnya gerakan-gerakan tarekat di Aceh pada awal abad ke-17, di bawah Hamzah Fansuri dan Syamsuddin Sumatrani serta pemberantasan di bawah Nuruddin Ar-Raniri adalah semata-mata karena dua orang yang pertama adalah dianggap sesat oleh masyarakat. Kehadiran Muhammadiyah pada tahun 1912 adalah merupakan gerakan amar ma'ruf nahi munkar yang berusaha keras menyeru masyarakat agar kembali kepada Al-Qur'an dan Hadis. Muhammadiyah harus menghadapi masyarakat atau budaya Jawa yang kental dengan khurafat, tahayyul dan bid'ah. Sebagai reaksi dari gerakan tersebut lahirlah Nahdatul Ulama (NU) pada tahun 1926. Muhammadiyah dianggap sebagai gerakan yang anti mazhab. ${ }^{18}$

Sidi Gazalba mengatakan bahwa sejarah adalah produk kebudayaan, begitu juga sebaliknya kebudayaan dibentuk oleh sejarah. Seluruh kehidupan kebudayaan dalam berbagai aspek kehidupan dikandung oleh tradisi. Namun tradisi itu berlaku dengan kuatnya, apabila tidak ada maksud untuk pewarisan masa lalu dengan langsung. Apabila orang menyatakan suatu pandangan, kepercayaan, menentukan ukuran, norma atau peraturan, menilai laku perbuatan, tradisi dipakai sebagai asas, pedoman dan atau perbandingan. Demikianlah tradisi merupakan syarat bagi keserbaterusan seluruh kehidupan kebudayaan. Tapi juga merupakan dasar dari kritik kebudayaan dan pembaharuan kebudayaan.

Di samping gejala tradisi terdapat pula lawannya dalam kehidupan kebudayaan, yaitu perubahan, peremajaan dan pembaharuan. Kehidupan itu bersifat tradisi, karena ia mempertahankan dan melanjutkan yang telah ada. Tetapi di samping itu ia juga selalu mempunyai kecenderungan untuk peremajaan dan pembaruan, seperti sifat yang umum pada tiap kehidupan. Bentuk-bentuk lama dapat bertahan di samping bentuk-bentuk baru. Apabila jarak antara yang lama dan yang baru terlalu jauh, ia dapat menimbulkan ketegangan atau konflik dalam masyarakat, seperti gejala umum yang kelihatan dalam akulturasi antara kebudayaan Barat dengan kebudayaan bersahaja atau yang belum berkembang. Peremajaan dan pembaruan karena mau mengubah yang lama, melahirkan ketegangan dan konflik. Sebabnya yang lama dengan tradisinya menjawab tantangan perubahan itu. Apabila yang baru Itu bertentangan dengan yang lama, suatu keadaan krisis akan lahir.

Pembaruan itu dapat terjadi karena perkembangan kebudayaan itu sendiri, mungkin pula karena pengaruh kebudayaan lain. Akulturasi lebih banyak menyebabkan pembaharuan kebudayaan. Dalam kebudayaan bersahaja hampir tidak ada perubahan atau pembaharuan. Tradisi hampir berlaku pasti di sini. Kuatnya kewibawaan tradisi, karena kebudayaan itu terpencil (geisoleerd). Tidak ada kontak dengan kebudayaan lain, sehingga tidak ada perbandingan, tidak ada perangsang untuk meniru, meminjam atau mengambil alih unsur-unsur kebudayaan asing, atau mewujudkan unsur baru. Karena tidak ada kontak, akulturasi tidak lahir. Pada kebudayaan yang tengah berkembang karena akulturasi, terdapat suasana tegang, karena pertentangan antara unsurunsur kebudayaan lama dengan yang baru. Ada golongan dalam masyarakat yang

\footnotetext{
${ }^{17}$ Asry, M. Yusuf, ed, Profil Paham dan Gerakan Keagamaan (Jakarta: Puslitbang Kehidupan Keagamaan, CV Prasasti, 2009), h. 176 - 177.

${ }^{18}$ Kuntowijoyo, Pengantar Ilmu Sejarah (Yogyakarta: Yayasan Bentang Budaya, 2001), h. $130-131$.
} 
mempertahankan yang lama, di samping golongan yang mengambil alih atau menciptakan yang baru. Terjadi konflik antara tradisi dan pembaruan. Karena itu masyarakat yang tengah mengalami akulturasi itu berada dalam krisis.

Krisis bangsa-bangsa terbelakang yang memperoleh kontak dengan bangsabangsa Barat adalah krisis kebudayaan, yaitu perpaduan antara kebudayaan yang rendah tingkatnya dengan kebudayaan yang sudah tinggi tingkatnya. Makin jauh jarak tingkat kebudayaan itu, yaitu antara kebudayaan asli dengan kebudayaan asing yang datang, makin intensif krisisnya. Dalam hal ini sesungguhnya kita menghadapi pertentangan yang lama (kebudayaan asli) dengan yang baru (kebudayaan asing modern). ${ }^{19}$ Dengan demikian yang dimaksud dengan pembaruan dalam penelitian ini adalah suatu usaha untuk mengubah kebiasaan lama di masyarakat yang tidak lagi sesuai dengan perkembangan zaman namun tanpa meninggalkan kearifan lokal.

Menurut bahasa, pemikiran berasal dari kata dasar فكر yang berarti proses, cara, atau aktifitas memikir, yakni menggunakan akal budi untuk memutuskan suatu masalah dengan mempertimbangkan segala sesuatu secara bijaksana. Dengan kata lain, pemikiran adalah upaya cerdas dari proses kerja akal dan kalbu untuk melihat gejala dan berusaha mencari solusinya secara bijaksana. ${ }^{20}$

Sedangkan pendidikan merupakan sutau proses penyiapan generasi muda untuk menjalankan kehidupan dan memenuhi tujuan hidupnya secara lebih efektif dan efisien $^{21}$. Pendidikan tidak hanya sebagai transfer of knowledge, melainkan transformasi nilai-nilai dan pembentukan karakter dengan segala aspeknya. Sementara pengajaran merupakan proses pengalihan ilmu pengetahuan daro seorang pengajar (guru) kepada orang yang diajar (murid, siswa, peserta didik).

Pendidikan adalah proses pembentuka individu berdasarkan ajaran Islam untuk mencapai derajat tinggi sehingga mampu menunaikan tugas ke khalifahannya dan berhasil mewujudkan kebahagiaan dunia dan akhirat. ${ }^{22}$ Pendidikan Islam lebih luas cakupannya dan lebih luhur tujuannya karena tidak hanya mencetak manusia menjadi orang yang berpengetahuan dan mampu menjalankan tugas kepemimpinan di dunia, namun juga mencetak manusia menjadi hamba Allah yang berbahagia di sisi Tuhannya (akhirat).

Pendidikan Islam berbeda dengan pendidikan sekuler (Barat) yang hanya membentuk manusia-manusia yang pandai di bidangnya (spesialis) dan menitik beratkan pada pencapaian kebahagiaan jasmani atau materi belaka dan tidak memperdulikan aspek moral, sehingga produknya adalah manusia-manusia intelek namun tidak bermoral dan dengan mudahnya mereka menggunakan ilmu pengetahuan mereka demi kepentingan individual semata, tidak demi kemaslahatan umat. Pendidikakn Islam lebih mengarahkan manusia untuk meraih kebahagiaan dunia dan akhirat secara seimbang, tahu bagaimana berakhlak yang baik terhadap Allah sebagai Penciptanya, terhadap sesama manusia maupun makhluk Tuhan yang lainnya.

Secara terminologi, pemikiran pendidikan Islam adalah serangkaian proses kerja akal dan kalbu yang dilaksanakan secara serius dalam melihat berbagai masalah yang ada dalam pendidikan Islam dan berusaha untuk membangun paradigm pendidikan yang mampu menjadi wahana bagi pembinaan dan pengembangan peserta didik secara paripurna ${ }^{23}$ Jadi lewat pendekatan ini diharapkan pendidikan Islam mampu menghantarkan peserta didik menjadi manusia seutuhnya, bukan hanya cerdas dan berilmu, melainkan juga berakhlakul karimah.

\footnotetext{
${ }^{19}$ Sidi Gazalba, Pengantar Sejarah Sebagai Ilmu, (Jakarta : Bhratara Karya Aksara, 1981), h. 148-149.

${ }^{20}$ A. Susanto, Pemikiran Pendidikan Islam, (Jakarta: Amzah, 2009), h. 2-3.

${ }^{21}$ Azyumardi Azra, Pendidikan Islam: Tradisi dan Modernisasi Menuju Milenium Baru, (Jakarta: Logos Wacana Ilmu, 2002), h. 3.

${ }^{22}$ Abudin Nata, Sejarah Pendidikan Islam Pada klasik dan Pertengahan, (Jakarta: Raja Grafindo), h. 10.

${ }^{23}$ A. Susanto, Pemikiran Pendidikan Islam, (Jakarta: Amzah, 2009), h. 3-4.
} 
Dengan demikian yang dimaksud dengan pembaruan pemikiran pendidikan Islam adalah usaha mereformasi pendidikan yang dilakukan Muhammad Basiuni Imran di Sambas pada tahun 1906 sampai 1976. Usaha reformasi pendidikan Islam tersebut adalah mengintegrasikan kurikulum agama dan umum, memperkenalkan koedukasi dan manajemen pendidikan berbasis administrasi.

\section{B. Biografi Muhammad Basiuni Imran}

Muhammad Basiuni Imran dilahirkan di Sambas pada tanggal 25 Zulhijjah $1302 \mathrm{H}$ bertepatan dengan 16 Oktober 1885 M. ${ }^{24}$ Muhammad Basiuni Imran dan tiga saudaranya diasuh oleh ibu tirinya bernama Badriyah, karena ibu kandungnya wafat saat mereka masih kecil. Badriyah adalah seorang yang bijak dan mengerti tanggung jawabnya sebagai pengganti ibu kandung Muhammad Basiuni Imran dan saudaranya. Ia sangat sayang kepada keempat anak tersebut bahkan menganggap mereka seperti anak kandungnya sendiri. ${ }^{25}$

Muhammad Basiuni Imran menikah dengan Muzinah H. Hamid. Dari perkawinannya itu, Muhammad Basiuni Imran memperoleh enam orang anak yaitu Wahajah, Hasibah, Sabihah, Hanunah, No'ma dan Rasyid. ${ }^{26}$ Muhammad Basiuni Imran menikah lagi dengan seorang perempuan bernama Mas Marhana. Dari pernikahan ini Muhammad Basiuni Imran memperoleh tiga orang putri dan tujuh putra yaitu Maunah, Makinah, Sahal, Badran, Dawyah, Nazimi,Taqiuddin, Riyat, Jamaluddin, dan Mustafa Imran. ${ }^{27}$

Dalam hidup keseharian, ia adalah orang yang sangat sederhana dan akrab bergaul dengan siapa saja, termasuk dengan penganut agama lain. ${ }^{28} \mathrm{Hal}$ ini mengindikasikan bahwa Muhammad Basiuni Imran adalah sosok yang toleran, akomodatif, dan tasāmuh tidak membeda-bedakan pergaulan berdasarkan agama dan itulah realitas pada masyarakat Sambas yang plural. ${ }^{29}$

Muhammad Basiuni Imran wafat di Pontianak pada tanggal 25 Juli 1976 karena sakit dan usia yang sudah lanjut. Usia Muhammad Basiuni Imran ketika meninggal berumur lebih kurang 91 tahun. Keesokan harinya, tanggal 26 Juli 1976 jenazahnya dibawa ke Sambas dan disalatkan di Masjid Raya Sambas. Ia dimakamkan di pemakaman keluarganya di Kampung Dagang Timur, Sambas. ${ }^{30}$ Masyarakat Sambas merasa kehilangan sosok ulama yang tidak ada gantinya, terlihat begitu ramai masyarakat yang ikut mengantar jenazah ke liang kubur.

Pada usia 7 tahun Muhammad Basiuni Imran belajar di lembaga pendidikan formal yaitu sekolah rakyat dan belajar agama secara informal kepada ayahnya. Setelah berusia 17 tahun yaitu tahun 1319 H, Muhammad Basiuni Imran pergi ke Mekah untuk menunaikan ibadah haji dan dilanjutkannya dengan belajar disana selama 5 tahun (1319-1324 H / 1901-1906 M). Selama berada di Mekah ia belajar pada Tuan Guru Umar Sumbawa, Tuan Guru Usman Sarawak, Tuan Guru Syekh Ahmad Khatib al-Minangkabau dan Syaikh Ali Maliki (Arab).

Setelah mengajar selama dua tahun di Sekolah al-Sultaniyah, ia melanjutkan pendidikan ke Mesir dari tahun 1909 sampai 1913. Di Mesir inilah ia mendalami pembaruan pemikiran Islam Muhammad Rasyid Rida yang tidak lain merupakan gurunya. Pada tahun 1913 ia dilantik menjadi Maharaja Imam kerajaan Sambas menggantikan ayahnya. ${ }^{31}$ Ketika menjadi Maharaja Imam, Muhammad Basiuni Imran

${ }^{24}$ A. Muis Ismail, Mengenal Muhammad Basiuni Imran, h. 13.

${ }^{25}$ Muhammad Rahmatullah, Pemikiran Fiqh Maharaja Imam Kerajaan Sambas, h. 63.

${ }^{26}$ A. Muis Ismail, Mengenal Muhammad Basiuni Imran, h. 13.

${ }^{27}$ A. Muis Ismail, Mengenal Muhammad Basiuni Imran, h. 14.

${ }^{28}$ Erwin Mahrus, Falsafah dan Gerakan Pendidikan Islam, h. 32.

${ }^{29}$ Masyarakat yang mendiami Sambas terdiri dari bangsa Melayu, Dayak, Cina dan bangsa

eropa.

${ }^{30}$ Erwin Mahrus, Falsafah dan Gerakan Pendidikan Islam, h. 36.

${ }^{31}$ G.F. Pijper, Beberapa Studi Tentang Sejarah Islam, h. 144. 
bertekad membangun pendidikan Islam dengan harapan agar umat Islam bisa maju seperti bangsa Barat.

Upaya membangun dan memajukan bidang pendidikan di Sambas diawali dengan keterlibatannya dalam menangani kurikulum pada Madrasah al-Sultaniyah. Kemudian membentuk sebuah perkumpulan bernama Tarbiyatul Islam yaitu pendidikan modern. Perkumpulan ini kemudian memperbarui sistem pembelajaran dan kelembagaan madrasah al-Sultaniyah.

Dalam upaya membangun dan memajukan pendidikan Islam, Muhammad

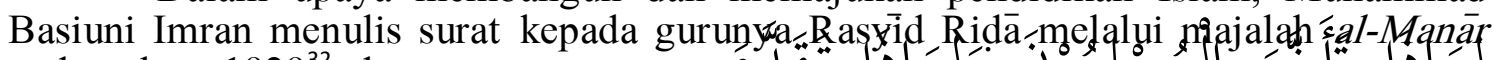

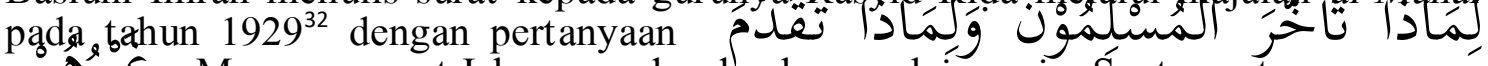
. عيرهُه . Mengapa umat Islam mundur dan bangsa lain maju. Śuatu pertanyaan yanǵ sempat menggemparkan dunia ketika itu dalam sebuah karya yang ditulis Amir Syakib Arselān. Amir Syakīb Arselān diperintahkan oleh Rasyid Riḍ̄a untuk menjawab pertanyaan Muhammad Basiuni Imran di atas, lalu Amīr Syakīb Arselān menjawabnya dengan membuat sebuah buku. Buku tersebut pada dasarnya belum menjawab secara keseluruhan dari pertanyaan Muhammad Basiuni Imran tersebut. Muhammad Basiuni Imran menulis surat tersebut tahun 1929 atau 21 Rabi'ul Akhir $1348 \mathrm{H}^{33}$ namun dimuat dalam majalah al-Manār pada tahun 1930 volume 31 nomor 5. Kemudian Amìr Syakỉb Arselān menjawab pertanyaan tersebut dalam sebuah buku dengan judul yang sama persis dengan pertanyaan yang disampaikan Muhammad Basiuni Imran pada tanggal 11 november $1930 .^{34}$

Kemudian pada masa pasca kemerdekaan Yayasan Pendidikan Islam (YASPI) Sambas menyelenggarakan program Kulliyatul Muballigin (pendidikan untuk para kader muballig) dan Muhammad Basiuni Imran diangkat sebagai pimpinan program ini pada tahun 1967. Dengan besluit Resident Borneo Barat No. 57 tertanggal 20 Pebruari 1946, Muhammad Basiuni Imran diangkat sebagai Adviseur (penasehat) dari Zelf bestuur commissie (semacam badan pemerintahan otonom) di Sambas. Pada tahun yang sama, dengan besluit Ratu Wilhelmina, Muhammad Basiuni Imran diangkat menjadi Ridder in de Orde van Oranje-Nassau (Pemimpin yang berprestasi dalam memajukan daerah). Di masa kemerdekaan Muhammad Basiuni Imran juga tetap bergerak di bidang politik. Karena aktivitas politiknya itu, ia diangkat sebagai anggota Konstituante RI mewakili partai Masyumi Kalimantan Barat hasil Pemilihan Umum Pertama tahun 1955. Masyumi dijadikan sebagai wadah perjuangan politik oleh Muhammad Basiuni Imran karena antara lain anggota partai ini banyak yang berlatar belakang lulusan Universitas al-Azhar, Mesir. ${ }^{35}$

Beberapa karya Muhammad Basiuni Imran yaitu Tarjamah Durūs al-Tärīkh alSyarī'ah (Terjemahan Pelajaran Sejarah Hukum Islam), Bidàyah al-Tauhìd Fï Ilm alTauhid (Permulaan keEsaan Allah dalam Ilmu Tauhid), Risalah Cahaya Suluh, Dzikr al-Maulid al-Nabāwí (Mengingat Kelahiran Nabi), Tazkīr (Peringatan), Khulāsăah Sirah al-Muhammadiyah (Ringkasan Sejarah Hidup Muhammad), Nür Siraj Fĩ Qișsah al-Isrā' wa al-Mi'räj (Cahaya Pelita pada Cerita Isra' dan Mi'raj), Al-Janāiz (Kitab Jenazah), Irsyād al-Ghilman Fï Adab Tilāwah al-Qur'ān (Petunjuk Praktis untuk anak tentang Adab Membaca al-Qur'an), Durüs al-Tauhïd (Pelajaran-Pelajaran tentang Tauhid), Dau' al-Misbāḥ Fỉ Faskh al-Nikāhh (Cahaya Lampu Untuk Membatalkan Nikah), Al-Nusūs wa al-Barāhin 'alā Iqàmah al-Jum'ah bimā Dūna al-Arbaīn. (Beberapa Dalii dan Argumentasi dalam Melaksanakan Shalat Jum'at yang Kurang dari Empat Puluh Orang), Husn al-Jawāb 'an Isbat al-Ahillah bi al-Hisab (Molek Jawaban tentang Menetapkan Awal Bulan Dengan Hitungan), Manhal al-Ghàribïn Fï Iqāmah al-Jum'ah bi dūna al-Arbaīn (Pendapat Orang yang Asing tentang

\footnotetext{
${ }^{32}$ Amīi Syakīb Arselān, Limā̇ā Taākhara al-Muslimūn wa Limāżā Taqaddama Ghairuhum

(Lebanon: Mansyurat Dar al-Maktabah al-Hayah, t.t.), h. 20.

${ }^{33}$ Amir Syakīb Arselān, Limā̄à Taākhara al-Muslimūn, h. 38.

${ }^{34}$ Amīir Syakīb Arselān, Limāzā Taākhara al-Muslimūn, h. 164.

${ }^{35}$ Erwin Mahrus, Falsafah dan Gerakan Pendidikan Islam, h. 42.
} 
Melaksanakan Shalat Jum'atKurang dari Empat Pulut Orang) dan Al-Tazkirah Badi'ah Fì Ahkāmil Jum'ah (Peringatan Bagi yang Mengada-ada dalam Hukum Shalat Jum'at).

\section{METODOLOGI PENELITIAN}

Jenis penelitian ini adalah penelitian sejarah dalam hal ini sejarah lokal. Dalam penelitian ini peneliti memilih penelitian kepustakaan atau library research dan penelitian lapangan/field research untuk melacak pembaruan pemikiran pendidikan Islam Muhammad Basiuni Imran. Data dapat diperoleh dari ide, gagasan, usaha dan karya-karyanya baik yang terpublikasi maupun tidak. Selain itu, untuk melakukan pengayaan informasi kepada anak kandung, keponakan, kolega, anak murid bahkan kepada tokoh agama dan tokoh masyarakat yang dirasa berkompeten memberikan informasi tentang Muhammad Basiuni Imran.

Lokasi penelitian ini adalah Sambas, sebagai tempat kelahiran Muhammad Basiuni Imran dan pada pertengahan abad 19. Penelitian ini menggunakan metode șejarah dengan pendekatan sosiologi, antropologi, prosopografi dan sejarah intelektual. Teori yang digunakan adalah teori pembaruan dan perubahan sosial. Penelitian ini juga menggunakan dua kajian yaitu pustaka dan lapangan. Kajian pustaka untuk melacak pemikiran pembaruan melalui karya-karyanya yang banyak. Sementara kajian lapangan melihat praktek pembaruan yang dilakukan Muhammad Basiuni Imran.

\section{PEMBARUAN PEMIKIRAN PENDIDIKAN ISLAM MUHAMMAD BASIUNI IMRAN}

Meskipun Kalimantan Barat sejak dahulu tidak banyak mempunyai pesantren sebagai tempat belajar yang formal seperti halnya Pulau Jawa, namun masih memiliki cukup banyak tempat belajar ilmu agama misalnya di kesultanan Pontianak dan Sambas. Sebagai contoh Sambas yang hampir setiap kampung memiliki orang alim/Tuan Guru yang di antaranya pernah bermukim sambil belajar agama beberapa tahun lamanya di Tanah suci Mekah dan Madinah. ${ }^{36}$ Oleh karena itu, daerah ini dikenal dengan julukan Serambi Mekah atau Serambi Mesir. Julukan ini berkaitan erat dengan kenyataan bahwa Sambas banyak memiliki ulama yang pernah belajar di Mekah dan Mesir. ${ }^{37}$

Pendidikan Islam di kerajaan Sambas sebenarnya telah mulai berkembang sejak masa kekuasaan sultan ke 2, yaitu Sultan Muhammad Tajuddin. Hampir pada setiap kampung telah didirikan surau, yang selain merupakan tempat ibadah juga menjadi tempat pengajian untuk memperdalam pengetahuan agama. ${ }^{38}$ Pelajaran yang diberikan mulai dari mempelajari huruf Arab Jawi sampai dengan membaca al-Qur'an. Pelajaran dasar-dasar keagamaan seperti ini biasanya dibimbing secara perorangan atau kelompok oleh seorang guru atau ulama, dan sejumlah murid lainnya duduk bersila menghadap guru. Fenomena pendidikan Islam tradisional seperti ini sebenarnya terjadi di daerah-daerah lain di nusantara.

Setelah masa kekuasaan sultan Muhammad Tajuddin, tidak terdapat perkembangan yang cukup menonjol dari masa sebelumnya. Sampailah pada masa pemerintahan Sultan Muhammad Tsafiuddin II (1866-1922) pendidikan Islam mengalami perkembangan pesat. Penguasa ke-13 kerajaan Sambas ini berupaya untuk mengembangkan dan meningkatkan kualitas keilmuan dan keagamaan di kalangan rakyat Sambas. Upaya tersebut direalisasikan dengan mendirikan sebuah masjid besar (Masjid Jami') di depan istana. Masjid ini didirikan pada tahun 1885 M. Selain itu, Sultan Muhammad Tsafiuddin II juga memberikan dorongan kepada pemuda-pemuda Sambas untuk belajar ilmu-ilmu agama ke luar negeri. Salah satu dari mereka kirim ke luar negeri adalah Muhammad Basiuni Imran yang belajar di Universitas al-Azhar,

\footnotetext{
${ }^{36}$ Mohd. Haitami Salim dkk, "Haji Muhammad Basiuni Imran Maharaja Imam Sambas (Studi Tekstual Latar Belakang Pendidikan, Kegiatan dan Penghargaannya)", Laporan Penelitian (Pontianak: Fakultas Tarbiyah IAIN Syarif Hidayatullah, 1998), h. 15.

${ }^{37}$ Erwin Mahrus, Falsafah dan Gerakan Pendidikan Islam, h. 2.

${ }^{38}$ Ansar Rahman, Kabupaten Sambas; Sejarah Kesultanan, h. 86.
} 
Kairo, Mesir. Dorongan untuk belajar ke luar negeri terutama di pusat-pusat keilmuan Islam antara lain dimaksudkan untuk mempersiapkan tenaga-tenaga yang nantinya akan mengisi jabatan keagamaan di pemerintahan kerajaan seperti jabatan Qadi dan Mufti serta menjadi tenaga pengajar pada madrasah al-Sultaniyah. ${ }^{39}$

Sebagai Maharaja Imam, Muhammad Basiuni Imran selalu berupaya untuk melakukan banyak hal yang berkaitan dengan tugas-tugasnya sebagai Qadi dan Mufti. la juga berperan besar dalam memajukan pendidikan di Kerajaan Sambas. Pengaruhnya sebagai Maharaja Imam dengan ilmu dan ide-ide pembaruan yang diperoleh dari guru-gurunya di Mesir dimanfaatkannya untuk mendorong Sultan untuk memajukan pendidikan Islam di Kerajaan Sambas.

Muhammad Basiuni Imran mempunyai perhatian yang cukup besar terhadap upaya memajukan pendidikan Islam ini antara lain ditunjukkannya dengan mengelola madrasah al-Sultaniyah, sebuah lembaga pendidikan yang sengaja disiapkan oleh Sultan Muhammad Syafiuddin II. Muatan kurikulum madrasah ini sepenuhnya berbasis materi keagamaan. Melekatnya citra keagamaan ini membuat masyarakat Sambas menyebut madrasạh ini dengan istilah Sekolah Arab. Madrasah Sultaniyah ini tetap berjalan dalam pemerintahan Sultan berikutnya. Tahun 1935 baru dirasakan kebutuhan untuk mendirikan sekolah yang mengajarkan ilmu pengetahuan umum di samping ilmu agama dengan organisasi seperti halnya sekolah model Barat. Sekolah ini diberi nama sekolah Tarbiyatul Islam. Perubahan ini kemudian berdampak pada perubahan sistem kelembagaan, metodologi dan kurikulum sekolah.

Kebijakan ini antara lain tampak dari pengembangan kurikulum pendidikannya, yakni pelajaran agama dan umum diajarkan bersama-sama. Materi pembelajaran pada sekolah Tarbiyatul Islam ini terdiri dari nahwu, sharaf, insya', tafsir, hadits, tauhid, berhitung, ilmu bumi, dan ilmu alam. Pendidikan yang dikembangkan oleh Muhammad Basiuni Imran tidak hanya menitikberatkan aspek moral dan keagamaan, tetapi juga memberikan kepada peserta didiknya pengetahuan dan keterampilan yang bersifat umum dengan tujuan membentuk kaum terdidik yang di samping memiliki pengetahuan agama yang cukup juga memiliki pengetahuan dan keterampilan. Pembaruan pendidikan Islam di atas, dilakukannya dengan hati-hati. Ia tetap menginginkan ciri Islam menjadi landasan bagi sebuah lembaga pendidikan, meskipun pada aspek tertentu ia bersikap terbuka terhadap pengaruh luar, antara lain dengan menerapkan kurikulum pendidikan Belanda pada sekolah yang ia dirikan. ${ }^{40}$

Pertumbuhan dan perkembangan pendidikan Islam pada awal abad ke-20 merupakan bagian dari gerakan pembaruan di Indonesia yang memiliki hubungan cukup intensif dengan gerakan pembaruan di Timur Tengah era modem. ${ }^{41}$ Pengaruh tokoh-tokoh pembaru Timur Tengah terhadap gerakan pembaruan umat Islam di Indonesia, termasuk Sambas, dimungkinkan antara lain karena terbukanya kesempatan bagi warga masyarakat Islam di tanah jajahan untuk memperdalam Islam di beberapa pusat pendidikan Islam, khususnya Kairo, Madinah dan Mekah. Kesempatan segmensegmen tertentu dalam masyarakat Melayu Indonesia untuk mengakses pusat-pusat keilmuan dan keagamaan di Timur Tengah tidak terlepas dari kemakmuran kerajaan muslim di Nusantara, terutama hasil perdagangan internasional. ${ }^{42}$ Peluang tersebut banyak digunakan oleh pemuda terkemuka pada masa itu untuk belajar di kota-kota tersebut, sehingga mereka dapat menyerap langsung suasana pembaruan yang sedang gencar ditawarkan oleh tokoh-tokoh seperti Jamaluddin al-Afghani, Muhammad

\footnotetext{
${ }^{39}$ Erwin Mahrus, Falsafah dan Gerakan Pendidikan Islam, h. 4.

${ }^{40}$ Erwin Mahrus, Falsafah dan Gerakan Pendidikan Islam, h. 6.

41 Dengan menggunakan rentang waktu antara tahun 1900 sampai dengan 1945, Karel A.
} Steenbrink, Beberapa Aspek Tentang Islam di Indonesia Abad ke 19, (Jakarta: Bulan Bintang, 1994), h. 26-29, mengdentifikasi paling tidak ada tiga faktor yang mendorong gerakan pembaman di Indonesia awal abad ke-20, antara lain: (1) faktor semangat nasionalisme melawan penjajah, (2) Faktor memperkuat basis gerakan sosial, ekonomi, budaya dan politik; dan (4) Faktor pembaruan pendidikan Islam di Indonesia.

${ }^{42}$ Azyumardi Azra, Jaringan Ulama Timur Tengah, h. 17. 
Abduh, dan Rasyid Riḍā. Dalam korespondensi mereka, pemuda-pemuda asal Indonesia yang telah menyerap pendidikan dalam suasana pembaruan itu memperkenalkan ide-ide pembaruan pada rekan- rekannya di Tanah Air.

Sementara Indonesia waktu itu pertumbuhan pendidikan Islam merupakan usaha penyesuaian terhadap tradisi persekolahan yang dikembangkan pemerintah kolonial Belanda. Mengingat struktur dan mekanismenya yang hampir sama, maka sekilas dapat diduga bahwa sistem pendidikan Islam di Indonesia merupakan bentuk lain dari sekolah kolonial Belanda yang diberi muatan dan corak keislaman. ${ }^{43}$ Secara umum pembaruan di kalangan umat Islam di Indonesia tampaknya dipengaruhi oleh pemikiran dan usaha-usaha pembaruan yang dilakukan oleh para tokoh reformasi Timur Tengah pada akhir abad ke-19, khususnya Jamaluddin alAfghani dan Muhammad Abduh. Kedua tokoh ini dipandang sangat penting kontribusinya pada pembaruan Islam di dunia dan khususnya di negeri- negeri yang sebagian besar beragama Islam, termasuk Indonesia.

Meskipun ciri gerakan pembaruan Islam itu menunjukkan anti-Barat, karena praktek penjajahan yang mereka lakukan terhadap negeri-negeri yang mayoritas muslim, Jamaluddin al-Afgani dan Muhammad Abduh memberi dukungan kepada umat Islam untuk mempelajari ilmu pengetahuan Barat yang lebih luas agar dengan demikian mereka dapat melawan Barat. Dalam kaitan inilah mereka menyerukan penataan sistem kelembagaan sosial, politik, ekonomi termasuk pendidikan yang memungkinkan umat Islam dapat mengembangkan bidang-bidang tersebut dengan lebih maju.

Pola-pola pendidikan di negara-negara Arab sejak awal abad ke-19, memang sudah mendapat tantangan untuk berubah dengan diperkenalkannya teknologi dari sistem pendidikan modern seiring dengan usaha negara-negara Barat untuk menjajah bangsa-bangsa Asia dan Afrika. Usaha modernitas selalu menjadi pikiran bagi pemerintah yang berkuasa untuk menjawab tantangan itu. Merujuk pendapat Mona Abaza $^{44}$ mengatakan Al-Azhar mengalami banyak pembaruan, khususnya setelah penjajahan Bonaparte di Mesir dan gerakan modernitas oleh Mohammad Ali pada permulaan abad ke-19, mahasiswa yang belajar di negara-negara Eropa seperti Rifaat al-Tahawi, 'Ayyad al-Tantawi, kemudian Muhammad Abduh dan Sa'ad Zaghloul, melakukan perubahan dan memberikan sumbangan bagi proses pembaruan.

Demikian pula halnya yang terjadi di Mesir awal abad ke-19 juga dirasakan oleh umat Islam di wilayah Asia Tenggara, khsusnya Indonesia. Eksistensi pendidikan Islam tradisional ditantang oleh kehadiran lembaga pendidikan Barat dalam bentuk sekolah yang dikembangkan oleh pemerintah kolonial. Sampai munculnya gerakan pembaruan akhir abad ke-19, respons at as tantangan ini masih bersifat isolasi, dimana pendidikan Islam mengasingkan diri dari pengaruh pendidikan modem.

Dalam waktu cukup lama, pendidikan Islam hanya mengkhususkan pembelajaran ilmu-ilmu keagamaan dan hampir tidak mengajarkan sama sekali mata pelajaran umum. Kehadiran madrasah atau sekolah berbasis agama pada awal abad ke20 dapat dikatakan sebagai perkembangan baru, di mana pendidikan Islam mulai mengadopsi mata pelajaran non keagamaan. Hal ini dimungkinkan karena gerakan pembaruan yang muncul dengan maju seperti halnya di negara Timur Tengah di bawah pengaruh Jamaluddin al-Afghani dan Muhammad Abduh. Madrasah atau sekolah yang demikian tidak sepenuhnya mencontoh sekolah Belanda, tetapi sangat mungkin juga merupakan proses logis dari gerakan pembaruan oleh umat Islam sendiri. ${ }^{45}$

Jurnal al-Manār memuat ide-ide pembaruan yang dibahas dalam aspek yang sangat luas termasuk masalah pendidikan. Jurnal ini juga membahas berbagai masalah

${ }^{43}$ Maksum, Madrasah; Sejarah Pertumbuhan dan Perkembangannya (Jakarta: Logos Wacana Ilmu, 1999), h. 88.

${ }^{44}$ Mona Abaza, Indonesian Students In Cairo (Paris: Association Archipel, 1994 ), h. 24.

${ }^{45}$ Maksum, Madrasah; Sejarah Pertumbuhan, h. 87. 
yang ditanyakan atau dikemukakan oleh para pembacanya. Misalnya pertanyaan yang diajukan oleh Muhammad Basiuni Imran tentang keunggulan sekolah-sekolah Barat dan ketertinggalan umat Islam. Mona Abaza ${ }^{46}$ menggambarkan : Banyak surat, pertanyaan dan artikel yang memusatkan masalahnya pada pendidikan. Dalam alManār vol. 30, No. 5, tahun 1930, halaman 353-354, Muhammad Basiuni Imran mempertanyakan secara kritis apakah hanya sekolah-sekolah Barat yang lebih baik dibandingkan sekolah-sekolah Islam.

Dalam al-Manār vol. 15 no. 9, $1330 \mathrm{H}$, Abdel Wahid bin Abdullah, seorang mahasiswa dan pondokan Jawi telah menulis sebuah artikel yang menggambarkan keterbelakangan masyarakat Jawi dalam pengetahuan keagamaan maupun pengetahuan non keagamaan. Satu-satunya pengajaran yang diberikan adalah melalui orang Belanda yang menjajah dan menyebarkan Misi Kristen. Namun demikian ia menekankan bahwa ia sangat bangga bahwa ada tiga mahasiswa Melayu Indonesia yang belajar di Madrasah Rasyid Rị̣ā, Dār al-Da'wah wa al-Irsyād. Ia juga menyatakan hararapan besarnya terhadap 30 mahasiswa Jawi yang kemudian belajar di al-Azhar. ${ }^{47}$

Wacana pendidikan yang muncul melalui al-Manār jelas relevan dengan masalah yang dihadapi di Nusantara. Pertanyaan yang diajukan Muhammad Basiuni Imran dan pelajar pelajar lainnya merupakan refleksi dari pergulatan dengan dunia Islam dan daerahnya, terutama pendidikan yang $d$ irasakan masih tertinggal. Gagasan dalam al-Manār dapat dijadikan pijakan untuk mencontoh perkembangan pembaruan pendidikan Islam, dalam bentuk madrasah atau sekolah umum yang berbasis agama yang tengah dilakukan kalangan pembaru Islam di Mesir khususnya Jamaluddin alAfghani, Muhammad Abduh dan Muhammad Rasyid Rị̣ā. Terlebih tokoh yang disebut terakhir telah memberi bentuk yang jelas tentang model pendidikan Islam yang ditawarkan dengan membangun madrasah Dàr al-Dakwah wa al-Irsyād yang justru diprioritaskan bagi mahasiswa Jawi di mana Muhammad Basiuni Imran dan saudaranya sempat belajar di sana.

Pada akhir abad ke-19, sekolah merupakan lembaga pendidikan yang eksklusif yang didirikan oleh pemerintah Belanda bagi kelompok terpilih menurut standar pemerintah. Namun mulai awal abad ke-20 atas perintah Gubernur Jenderal van Heutsz, sistem pendidikan itu mulai diselenggarakan bagi masyarakat luas dalam bentuk Sekolah Desa (Volkschool). Hal ini disebabkan karena pemerintah kolonial sangat berkepentingan akan adanya pendidikan rendah ini yang diarahkan untuk mendidik tenaga-tenaga terdidik rendahan yang bisa dipekerjakan pada pemerintahan kolonial atau pada usaha-usaha ekonomi mereka (khususnya sektor perkebunan). Selain Sekolah Rakyat, pemerintah kolonial juga mengembangkan sekolah yang lebih tinggi untuk mendidik tenaga-tenaga calon pegawai pemerintah. Pada Sekolah Rakyat, mata pelajaran yang diajarkan terbatas pada menulis, membaca dan berhitung. Pada sekolah yang lebih tinggi diajarkan pula mata pelajaran bahasa dan pengetahuan umum.

Perkembangan sekolah yang semakin merakyat dalam batas yang cukup jauh telah merangsang kalangan Islam untuk menyadari akan perlunya pendidikan, jika mereka tidak ingin tertinggal. Dalam hal ini kalangan Islam melihat bahwa diskriminasi untuk mendapat kesempatan pendidikan sangat tampak dalam politik dan kebijakan pemerintah kolonial. Maka sebagai respon terhadap kondisi seperti ini timbul upaya untuk membangun lembaga pendidikan Islam yang menawarkan pola pendidikan yang lebih maju daripada yang sudah ada, baik dalam hal kelembagaan, struktur materi, maupun metodologinya. Dengan demikian, dapat mengimbangi sekolah-sekolah yang didirikan pemerintah kolonial Belanda.

Pada awal abad ka-20, di Kalimantan belum terdapat organisasi Islam yang berbasis pandangan modern. Pemikiran modern pada umumnya hanya berkembang di kalangan perorangan. Di antara tokoh yang berpandangan maju pada masa itu adalah

\footnotetext{
${ }^{46}$ Mona Abaza, Indonesian Students In Cairo, h. 58.

${ }^{47}$ Mona Abaza, Indonesian Students In Cairo, h. 58.
} 
Muhammad Basiuni Imran. Kedudukannya sebagai Qadi kesultanan Sambas, maupun hubungan kekerabatannya dengan sultan menyebabkan aksesnya terhadap elit penguasa hampir tidak menemukan kendala yang berarti, bahkan ia merasakan situasi yang kondusif. Akses yang baik inilah dimanfaatkan oleh Muhammad Basiuni Imran untuk melakukan pembaruan pendidikan Islam di kesultanan Sambas. Muhammad Basiuni Imran mencoba melakukan revitaslisasi pelaksanaan ajaran Islam; dengan menyesuaikan pendidikan Islam dengan perkembangan yang terjadi sebagai akibat dari kehadiran sekolah-sekolah pemerintah Belanda dan sekolah missi Katolik di Sambas.

Meskipun bukan seorang ahli pendidikan yang banyak melahirkan banyak teori tentang pendidikan namun terdapat sejumlah pandangan Muhammad Basiuni Imran dalam bidang pendidikan patut untuk dicermati sebagaimana tertuang dalam statuten en Huishoudelijk Reglement (AD/ART) perkumpulan Tarbiyatul Islam dan dua naskah yang sengaja ia tulis untuk mengisi ceramah pada Kulliyatul Muballighin.

Pertama, pendidikan Islam tidak mengenal dikotomi. Pendidikan Islam menurut Muhammad Basiuni Imran bersifat utuh menyeluruh dan tidak mengenal pemisahan ketat antara ilmu agama (ulumuddin) dan ilmu umum (ulumuddunya). Pandangan pendidikan non dikotomik ini tertuang dalah AD/ART perkumpulan Tarbiyatul Islam yang dibentuknya. Muhammad Basiuni Imran menegaskan bahwa, Tarbiyatul Islam adalah satu satunya perkumpulan di Kota Sambas yang berpendirian semata mata dalam jurusan sosial. Pengurusnya bercita cita membangunkan sekolah sekolah yang berpelajaran dan berpendidikan lahir dan batin pada jalan dunia akhirat. ${ }^{48}$ Untuk merealisasikan cita-cita di atas, ia jabarkan perkumpulan sebagai berikut: Pertama, dirikan sekolah yang mengajarkan dasar-dasar ilmu agama Islam dan memasukkan seluruh pelajaran di lembaga pendidikan Belanda yaitu Holland Inlansche School (HIS). Kedua, membuka kursus-kursus agama untuk para muballigh. Ketiga, mengadakan pertemuan pertemuan yang membahas persoalan-persoalan agama.

Statuten ini secara gamblang menggambarkan corak pendidikan Islam yang diinginkan Muhammad Basiuni Imran. Kehadiran sebuah lembaga pendidikan yang berangkat dari pertimbangan politik dan kebutuhan masyarakat sebagaimana yang disampaikan oleh Pangeran Tumenggung Jaya Kusuma ${ }^{49}$ bahwa Nusa dan Bangsa tidak akan lekas majunya, kalau tidak ada perguruan bangsanya sendiri. Pertimbangan politik didorong oleh kebijakan pemerintah kolonial Belanda yang akan membubarkan HIS. Di sisi lain lembaga pendidikan yang menjanjikan aspek kemodernan hanya disediakan oleh sekolah-sekolah milik misi Katolik.

Sementara itu pertimbangan kebutuhan masyarakat dipicu kesadaran bahwa lembaga pendidikan Islam yang telah ada yaitu madrasah al-Sultaniyah dipandang kurang mampu bersaing jika hanya mempertahankan corak pendidikan tradisional. Maka untuk menjawab tantangan modernitas di tengah masyarakat yang terus berubah itulah yang mendorong Muhammad Basiuni Imran membentuk Perkumpulan Tarbiyatul Islam.

Pada tataran praksis, dalam mengajarkan ilmu agama Muhammad Basiuni Imran cenderung menggunakan metode terutama gagasan pembaruan yang dikembangkan oleh jurnal al-Manār seperti telah disinggung di muka. Sedangkan dalam mengajarkan ilmu umum ia cenderung menggunakan kurikulum Barat yang dikembangkan oleh pendidikan kolonial (Belanda).

Kedua, Syarat-syarat seorang pendidik. Dalam pandangan Muhammad Basiuni Imran syarat seorang pendidik ini dapat dikelompokkan dalam dua kategori yaitu syarat moral seperti ikhlas, sabar dan bijaksana, dan menjauhi perdebatan. Kemudian syarat profesional meliputi pengetahuan yang luas dan mengetahui keadaan peserta didik. Pembahasan tentang ikhlas dimulai dengan mengemukakan definisi ikhlas secara lughah (bahasa) dan istilah. Ia misalnya menyebut ikhlas berasal dari kata kerja akhlasa, yukhlisu, ikhlāsan yang artinya membersihkan. Bersikap ikhlas adalah

\footnotetext{
${ }^{48}$ statuten Tarbiyatul Islam 1936.

${ }^{49}$ Pangeran Tumenggung Jaya Kesuma, Laporan Tentang Kontrak, h. 25.
} 
membersihkan hati dari segala kekotoran. Mengerjakan sesuatu semata-mata karena Allah karena beriman dan mengharap rida-Nya. Sikap ikhlas bagi Muhammad Basiuni Imran adalah ruh atau jiwa dari suatu perbuatan. Perbuatan tanpa ikhlas adalah hampa. ${ }^{50}$ Keahliannya dalam bidang tafsir ikut mewarnai tulisannya. Sebagai bukti adalah dikemukakannya beberapa ayat sebagai dasar penjelasannya, di samping beberapa hadis dan pendapat para ulama.

Ide memodernisir madrasah al-Sultaniyah menjadi sekolah Tarbiyatul Islam didorong oleh situasi ketika pemerintah kolonial Belanda berencana akan membubarkan HIS menyusul krisis ekonomi di Sambas pada 1933. Sedangkan antusiasme putera-puteri Sambas untuk belajar bahasa Belanda dan pengetahuan umum cukup besar. Satu-satunya sekolah umum yang ada pada waktu itu hanya sekolah misi milik Katolik. Berdirinya sekolah misi di Sambas ini mendorong Muhammad Basiuni Imran bergerak cepat karena sadar bahwa adanya sekolah umum yang menarik anak-anak dari lapisan masyarakat atas dan menengah, akan berdampak merugikan pendidikan Islam yang sudah ada pada waktu itu dan sebagai upaya membendung arus misi katolik. ${ }^{51}$ Untuk menyikapi kondisi ini, Muhammad Basiuni Imran mengadakan pertemuan dengan beberapa tokoh di Sambas seperti dr. Syahrial dan Ali Imran (seorang guru HIS). Dalam pertemuan itu diputuskan madrasah alSultaniyah akan dijadikan schakel school, dengan pola pembelajaran seperti sekolah umum Belanda, namun tetap mempertahankan ciri pendidikan Islam.

Berdasarkan uraian di atas, setidak-tidaknya terdapat 3 alasan yang mendasari pertimbangan perubahan madrasah al-Sultaniyah menjadi sekolah Tarbiyatul Islam. Pertama, situasi krisis akibat anjloknya harga hasil perkebunan di pasaran dunia. Pada satu sisi kondisi ini memaksa pemerintah kolonial mengurangi anggaran pendidikan dan akhirnya menutup beberapa Sekolah Rakyat yang mereka dirikan. Di sisi lain, kondisi krisis ini menyebabkan pemerintah kolonial menutup beberapa usaha perkebunan yang berdampak pada hilangnya lapangan pekerjaan bagi masyarakat, terutama kalangan menengah ke bawah, semakin menyadarkan mereka bahwa pendidikan merupakan jaminan bagi masa depan seseorang. Kedua, antusiasme masyarakat terhadap pendidikan, khususnya lapisan atas dan menengah di Sambas terhadap pendidikan sebagai konsekuensi dari proses modernisasi yang diperkenalkan oleh pemerintah kolonial. Ketiga, motif agama. Agama Katolik dengan lembagalembaga misinya seperti sekolah, gereja, dan rumah sakit yang berkembang sangat pesat. Dalam konteks yang disebut terakhir Muhammad Basiuni Imran tidak menginginkan lembaga- lembaga pendidikan Islam tertinggal.

Untuk mengelola madrasah al-Sultaniyah yang berbentuk schakel school itu secara profesional, maka dibentuklah perkumpulan Tarbiyatul Islam pada tahun 1936. Perkumpulan ini memiliki motto, sebagaimana yang digaungkan oleh Pengeran Tumenggung Jaya Kusuma "Nusa dan Bangsa tidak akan lekas majunya jika tidak memiliki perguruan bangsanya sendiri”. Schakel school itu kemudian diberi nama sekolah tarbiyatul Islam.

Berdirinya perkumpulan Tarbiyatul Islam dengan sekolah-sekolahnya bertujuan untuk dapat realisasikan gagasan-gagasan pembaruan dalam pikiran Muhammad Basiuni Imran. Sisi-sisi pembaruan ini tampak dalam lembaga-lembaga pendidikan ia dirikan dan atau ia pimpin. Berdasarkan Statuten (1936) perkumpulan Tarbiyatul Islam bertujuan: memajukan dan menggembirakan (menggemarkan) pengajaran dan pelajaran agama Islam dalam kerajaan Sambas serta memajukan cara kehidupan sepanjang kemauan agama Islam kepada anggota-anggotanya.

Perubahan madrasah al-Sultaniyah menjadi sekolah Tarbiyatul Islam, membuat Muhammad Basiuni Imran melakukan perubahan terhadap sistem pendidikan. Sistem klasikal yang telah diterapkan di madrasah al-Sultaniyah sejak

\footnotetext{
${ }^{50}$ Muhammad Basiuni Imran 1967a.

${ }^{51}$ Wawancara dengan H. Kamaluddin, tokoh agama yang mengenali Muhammad Basiuni Imran di Sambas.
} 
1918 tetap ia pertahankan. Namun lembaga pendidikan yang telah memakai tingkatan kelas dari kelas 1 sampai 5, sebagai respon atas penyesuaian terhadap Sekolah Rakyat pemerintah kolonial ini, diperluas dengan menerapkan masa selama 7 tahun dengan memberlakukan kelas 1 sampai 7 di ruangan terpisah. Perpanjangan masa belajar ini dimungkinkan menyusul akan diperluasnya kurikulum sekolah Tarbiyatul Islam. Akibat lebih jauh dari perluasan ini, dipindahkannya lokasi sekolah semula di Istana ke luar lingkungan istana.

Sistem ko-edukasi di masa-masa awal berdirinya sekolah Tarbiyatul Islam telah dikenalkan, dimana siswa laki-laki maupun siswa perempuan belajar dalam kelas yang sama. Dalam hal ini, sekolah Tarbiyatul Islam lebih maju dibandingkan sekolah Katolik pada umumnya kerana sistem pendidikan misi Katolik masih memisahkan antara siswa laki-laki dan perempuan dalam sekolah tersendiri. Pada masa berdirinya sekolah Tarbiyatul Islam di Sambas telah berdiri pula Vervoolg school untuk siswa laki-laki dan Misis Vervoolg school bagi siswa perempuan. Di sekolah Tarbiyatul Islam juga telah diperkenalkan sistem administrasi sekolah seperti absensi kelas, evaluasi dan daftar nilai (rapor), serta ijazah sebagai tanda tamat belajar.

a. Madrasah al-Sulthaniyah

Pada masa-masa awal berdirinya, kurikulum madrasah al-Sultaniyah terbatas pada muatan pelajaran yang bersifat keagamaan. Beberapa perubahan dilakukan Muhammad Basiuni Imran bersama Ahmad Fauzi dan Abdurrahman Hamid sepulang menuntut ilmu di Makkah dan Mesir. Sementara itu, kebijakan pemerintah kolonial mendirikan sekolah sekolah rakyat di kalimantan Barat, membuat keberadaan madrasah al-Sultaniyah ditantang oleh kehadiran lembaga pendidikan kolonial tersebut. Mulai saat itu disamping memasukkan kurikulum agama yang seluruhnya merupakan kitab standar berbahasa Arab yang ditulis oleh pakar dari Timur Tengah seperti kitab al-Isläm: Syari'ah wa Aqīdah (Mahmud Syaltut), Fath al-Qaīib (Muhammad Ibn Oasim), Jawāhir al-Kalamiyah (Husein al-Jisr), Husn al-Hamidiyah (Husein Affandy), al-Lughah al-Arabiyah (Hefni Beik), dan Kalimah al-Tauhìd (Husein Wali). Madrasah al-Sultaniyah di bawah pengawasan Basiuni Imran, sedikit demi sedikit membuka diri dengan memasukkan mata pelajaran umum seperti berhitung, membaca dan menulis huruf Latin.

Hal yang menarik untuk dicermati adalah tidak dijadikannya karya tulis (kitab-kitab) Muhammad Basiuni Imran sebagai bahan rujukan dalam kurikulum madrasah al-Sultaniyah, sekolah Tarbiyatul Islam maupun program Kuliyyatul Muballigin. Pertimbangan ini dapat dilihat dari beberapa hal berikut. Pertama, kitab atau risalah risalah Muhammad Basiuni Imran dimaksudkan untuk merespon permasalahan yang timbul di masyarakat Sambas, sehingga tujuannya adalah untuk memberikan fatwa dan ketentuan hukum yang berlaku. Kedua, tempat terbit karya Muhammad Basiuni Imran yang hampir seluruhnya di percetakan al-Matba'ah alAhmadiyah Singapura dan sebagian di percetakan al-Manär Kairo sangat berpengaruh pada wilayah peredaran dan daya beli masyarakat. Ketiga, tampaknya Muhammad Basiuni Imran menghendaki agar keluasan ajaran Islam dipelajari dan dipahami dari sumber-sumber aslinya yang berbahasa Arab terbitan Timur Tengah.

b. Sekolah Tarbiyatul Islam

Setelah madrasah al-Sultaniyah dimodernisasi menjadi sekolah Tarbiyatul Islam, bahasa pengantar dalam proses pembelajaran yang semula menggunakan bahasa Melayu lama dan aksara Arab Jawi mulai diperbarui. Sekolah Tarbiyatul Islam, siswa sejak kelas 1 sampai 3 menggunakan bahasa Melayu, sedangkan siswa kelas 4 sampai kelas 7 wajib menguasai bahasa Belanda.

Dalam statuten (1936) Tarbiyatul Islam disebutkan bahwa salah satu tujuan perkumpulan Tarbiyatul adalah, membangun dan membantu sekolah-sekolah yang diberikan dasar-dasar pelajaran agama Islam dan ilmu-ilmu yang biasa diajarkan di sekolah-sekolah seperti HIS dan sebangsanya. Untuk mendukung cita cita pendidikannya tersebut, lembaga yang berdiri 1 Juli 1936 ini mulai memasok tenaga pendidikan ahli dan berijazah, salah seorang di antaranya adalah Mursyid Idris. Di 
samping itu juga mendatangkan tenaga-tenaga pendidik yang berasal dari Sumatera Barat terutama perguruan al-Tawalib dan Perguruan Syafii di Kayu Tanam. ${ }^{52}$ Di antara mereka terdapat nama Bahrun Sutan Melano, yang kemudian pernah menjabat Kepala Dinas Pendidikan dan Kebudayaan Propinsi Kalimantan Barat. Perkembangan selanjutnya tenaga pengajar sekolah Tarbiyatul Islam sebagian besar adalah lulusan HIK (Holland Inlandsche Kweekschool) Bandung dan Yogyakarta, dan sebagian lagi dari madrasah al-Juneid Singapura. ${ }^{33}$

Kebijakan mendatangkan guru-guru dari luar Sambas antara lain dilatarbelakangi oleh kepentingan sekolah Tarbiyatul Islam akan tenaga-tenaga pengajar yang memiliki kualifikasi tinggi. Di sisi lain kebijakan ini juga berarti telah memasukkan pembaruan yang dibawa oleh guru-guru ini ketika mereka masih berada di pulau Jawa dan Sumatera yang dipandang sebagai daerah yang paling maju keilmuan dan keagamaannya di Nusantara. Guru-guru dengan kualifikasi seperti ini akan mampu mencetuskan ide-ide pembaruan di Sekolah dan lingkungan masyarakat. ${ }^{54}$

Usaha pembaruan lainya yang dilakukan oleh Muhammad Basiuni Imran adalah memasukkan ilmu pengetahuan modern ke dalam kurikulum Tarbiyatul Islam seperti sejarah, berhitung, ilmu alam, ilmu tumbuhan, ilmu hewan, ilmu manusia. Bahasa Belanda dan Bahasa Indonesia, di samping ilmu-ilmu keislaman lainnya. Menurut Muhammad Basiuni Imran, ilmu pengetahuan umum adalah sarana penting untuk mengejar kemajuan. Meskipun demikian, penguasaan ilmu ilmu tersebut tidak menyebabkan seseorang tercerabut dari akar keagamaannya. Dengan demikian, Muhammad Basiuni Imran menginginkan berdirinya lembaga pendidikan yang berorientasi pendidikan Belanda, karena membuka jalan untuk memperoleh pendidikan setinggi tingginya namun tetap berbasis pada pendidikan Islam.

Jika memperhatikan kurikulum sekolah Tarbiyatul Islam, akan kelihatan dengan jelas bahwa sekolah ini telah mengadopsi kurikulum HIS, sekolah elit milik pemerintah kolonial. Hal ini tampak pada materi pelajaran sekolah ini meliputi : bahasa Belanda, membaca, menulis, berhitung, ilmu bumi, ilmu tumbuhan, ilmu hewan, menggambar, senam pagi dan bernyanyi. Di samping persamaannya, perbedaan kurikulum HIS dengan sekolah Tarbiyatul Islam, tampak pada kurikulum agama. HIS tidak memasukkan kurikulum agama karena orientasi pendidikannya yang sekuler, termasuk juga pelajaran sejarah. Hal ini dimungkinkan karena pelajaran sejarah dianggap sensitif secara politis. Pada zamannya, terutama sebelum tahun 1930an, madrasah al-Sultaniyah masih dianggap mampu memenuhi harapan masyarakat dilihat dari aspek sosial keagamaan dan sosial ekonomi. Secara sosial keagamaan, lembaga pendidikan ini sesuai dengan lingkungan dan keyakinan masyarakat Melayu yang beragama Islam. Secara sosial ekonomi, al-Sultaniyah adalah lembaga pendidikan yang menjanjikan lapangan pekerjaan. Alumni lembaga pendidikan ini dapat diserap menjadi guru atau penghulu di wilayah Kesultanan Sambas.

Muhammad Basiuni Imran memandang bahwa pendidikan tradisional yang hanya bertahan dengan kurikulum agama dan tidak memasukkan ilmu ilmu pengetahuan umum belumlah memenuhi persyaratan untuk mampu bertahan di era modem. Sedangkan tantangan hidup pada zaman yang berubah pesat memerlukan ilmu pengetahuan yang cukup. Sejak perubahan madrasah al-Sultaniyah menjadi sekolah Tarbiyatul Islam, pelajaran yang bersifat nasionalisme pun mulai diajarkan. Pendidikan Tarbiyatul Islam mulai diarahkan untuk menjadi wahana pengembangan wawasan kebangsaan. Menurut H.A.R. Tilaar, ${ }^{55}$ pada masa kebangkitan nasional, pendidikan menyatu dengan gerakan kebangsaan. Ketika aparatur pemerintah Kolonial mulai 1983), h. 65.

${ }^{52}$ Pasifikus Ahok, Sejarah Pendidikan Daerah Kalimantan Barat (Pontianak: Depdikbud,

${ }^{53}$ Erwin Mahrus, Falsafah dan Gerakan Pendidikan Islam, h. 88.

${ }^{54}$ Erwin Mahrus, Falsafah dan Gerakan Pendidikan Islam, h. 89.

55 H.A.R. Tilaar, 50 Tahun Pembangunan Pendidikan Nasional 1954-1995, Suatu Analisis Kebijakan (Jakarta: Gramedia, 1995), h. 35. 
menindas gerakan kebangsaan, pendidikan merupakan sarana paling ampuh untuk menyalurkan cita-cita kemerdekaan.

Pengintegrasian kurikulum yang dilakukan Muhammad Basiuni Imran menunjukkan kepedulian yang sangat tinggi dari beliau untuk membekali anak didik dengan ilmu pengetahuan umum sekaligus membangkitkan semangat nasionalis. Semangat kebangkitan ini juga ternyata ditangkap oleh sekolah Tarbiyatul Islam. Kondisi ini mendorong Tarbiyatul Islam menjadi lembaga pendidikan yang lebih terbuka. Pendidikan kebangsaan yang dikembangkan oleh Tarbiyatul Islam melahirkan banyak kader. Beberapa orang guru Tarbiyatul Islam adalah anggota partai politik dan aktivis pergerakan pada waktu itu. Misalnya saja Mursyid Idris adalah anggota Partai Indonesia Raya (Parindra) Sambas. Izzuddin Zubir adalah aktivis Persatuan Muslimin Indonesia (PERMI) Demikian juga dengan Hamidi Abdurrahman yang aktif di Persatuan Bangsa Indonesia Sambas (PERBIS).

Di samping pendidikan formal di sekolah, Muhammad Basiuni Imran juga memandang perlu adanya pendidikan luar sekolah melalui dakwah Islam. Sebagai realisasinya ia mengadakan pengajian mingguan bagi masyarakat di sekitar ibu kota Kesultanan yang dipusatkan di Masjid Jami' Sambas. Sejak tahun 1947 an kepengurusan di Tarbiyatul Islam di bawah kendali guru Mahfus. ${ }^{56}$ Selain itu, Sambas yang dikenal sebagai serambi Makkah dan atau "Serambi Mesir", telah menjadi pusat pertemuan ulama-ulama di Kalimantan Barat antara tahun 1928 sampai 1940-an. Pertemuan berkala ini hendaknya tidak dipandang remeh. Signifikansi kontak seperti ini tidak hanya merupakan sarana pertukaran informasi tentang berbagai isu. Tetapi lebih penting lagi adalah menghubungkan komunitas ulama yang mempunyai arti penting bagi perkembangan keilmuan dan keagamaan di Kalimantan Barat.

Di zaman kemerdekaan di era tahun 1960-an, pada usia 80-an Muhammad Basiuni Imran masih tetap aktif memimpin Kulliyatul Muballigin yang diselenggarakan oleh Yayasan Pendidikan Islam (YASPI) Sambas. Kiprah dan karirnya ini menunjukkan bahwa gerakan Muhammad Basiuni Imran merupakan kontinuitas gagasan pembaruannya dalam pendidikan Islam di Sambas, meskipun tidak lagi dalam wadah perkumpulan atau institusi yang sama. ${ }^{57}$

\section{c. Kulliyatul Muballigin}

Kulliyatul Muballigin merupakan pendidikan bagi muballigh yang difasilitasi oleh Yayasan Pendidikan Islam (YASPI) Sambas. Yayasan ini terbentuk atas inisiatif salah seorang tokoh Islam Sambas yang bernama Murtaba Muhammad Chan pada 20 April 1963. Ide pembentukan YASPI Sambas antara lain didorong oleh keinginan pengurusnya untuk melakukan modernisasi pendidikan Islam yang sesuai dengan tuntutan zaman, dan tidak mau ketinggalan dari lembaga-lembaga pendidikan kalangan luar agama Islam, terutama sekolah misi Katolik di Sambas. Untuk merealisaasikan keinginannya itu, YASPI Sambas bercita-cita mendirikan lembagalembaga pendidikan Islam mulai tingkat dasar, menengah, atas, dan perguruan tinggi. ${ }^{58}$

Dalam perjalanan sejarahnya, YASPI Sambas banyak mengalami kendala, terutama situasi politik nasional menjelang meletusnya G.30 S/PKI yang berdampak pada stabilitas keamanan dan resesi ekonomi, tidak terkecuali di Sambas. Akibatnya aktivitas YASPI mengalami kevakuman total menjelang akhir tahun 1965. kondisi ini diperparah dengan pergolakan daerah berupa konfrontasi dengan Malaysia (1963-1966) di mana Sambas merupakan basis konsentrasi sukarelawan Indonesia berhadapan dengan Sarawak. Setelah tercapainya normalisasi hubungan Malaysia Indonesia, konfrontasi dihentikan.

Pasca normalisasi hubungan muncul persoalan baru yaitu penyusupan Pasukan Gerilyawan Rakyat Sarawak (PGRS) dan Pasukan Rakyat Kalimantan Utara

\footnotetext{
${ }^{56}$ Wawancara dengan H. Daeng Abu Bakar di Sambas, salah seorang murid Tarbiyatul Islam.

${ }^{57}$ Erwin Mahrus, Falsafah dan Gerakan Pendidikan Islam, h. 91.

${ }^{58}$ AD/ART YASPI Sambas 1963.
} 
(PARAKU) yang memasuki wilayah Sambas. Gerilyawan yang pro komunis ini bergabung dengan sukarelawan PKI dan kelompok Cina Komunis Kalimantan Barat yang anti Malaysia lalu melakukan kekacauan di daerah Paloh, Sungai Bening, Sajingan, Beruang, Seluas, dan Jagoi Babang. Situasi gejolak daerah seperti ini berlangsung dari 1966-1973. Meskipun situasi daerah yang kurang menguntungkan, YASPI Sambas sempat menyelenggarakan Kulliyatul Muballigin, sebuah program yang dimaksudkan untuk mempersiapkan tenaga-tenaga muballigh (dai) yang militan dan dapat dipertanggungjawabkan (kompeten) dalam usaha dakwah Islam yang meliputi upaya menanamkan benih pendidikan, pengajaran ${ }_{59}$ dan kebudayaan pada generasi muda atau anggota masyarakat menurut ajaran Islam. ${ }^{59}$

Besarnya kontribusi dalam melakukan pembaruan dan memajukan pendidikan di Sambas menyebabkan ia dipercaya sebagai Ketua Kehormatan YASPI sekaligus diangkat menjadi pimpinan Kulliyatul Muballigin. Menurut Murtaba M. Chan, program ini sebenarnya merupakan langkah awal untuk mendirikan perguruan tinggi Islam (Fakultas Ushuluddin) di Sambas. Pelaksanaan program Kulliyatul Muballigin dipusatkan di SMEA Negeri I (sekarang SMK Negeri 1) Sambas. Peserta program terdiri dan lulusan SMA sederajat, bahkan hampir seluruhnya telah memiliki pekerjaan tetap baik sebagai pendidik (guru) maupun sebagai pegawai pemerintah dan swasta. Penerapan metode pembelajarannya disesuaikan dengan peserta didiknya. ${ }^{60}$

Dalam Menyelenggarakan pendidikan Kulliyatul Muballigin, Muhammad Basiuni Imran tidak sembarangan menunjuk seseorang menjadi guru. Guru yang akan mengajar di sekolah ini diseleksi dan dites dengan harapan nantinya guru yang mengajar adalah benar-benar guru yang berkualitas yang pada akhirnya melahirkan lulusan yang unggul. Salah seorang guru di sekolah ini adalah Murtaba Muhammad Chan, bahkan ia satu-satunya guru yang mendapatkan ijazah dari Muhammad Basiuni Imran tidak sekedar sebagai guru melainkan mengajarkan agama Islam di Masjid Jamik kesultanan Sambas. ${ }^{61}$

Pendekatan yang digunakan dalam kelas Kulliyatul Muballigin adalah dengan pendekatan andragogi yaitu pendidikan orang dewasa, mengingat pesertanya terdiri dari orang-orang yang telah dewasa. Prosesi pembelajaran dimulai dengan penyampaian materi dan seorang penceramah selama 10 sampai 15 menit, kemudian dilanjutkan dialog (tanya jawab) antara penceramah dengan peserta program.

Kurikulum Kulliyatul Muballigin tidak hanya merujuk pada satu $\mathrm{kitab} /$ referensi melainkan kitab yang beragam. Bahkan di antara pengajar pada program ini sengaja menulis materi pembelajaran dalam bentuk naskah yang kemudian disimpan oleh YASPI Sambas. Bahan pembelajaran seluruhnya bermuatan materi keislaman.

Penekanan pada materi-materi keislaman ini dapat dimengerti mengingat hampir seluruh peserta program ini adalah guru atau pegawai pemerintah dan swasta. Walaupun demikian, Muhammad Basiuni Imran selalu mendorong peserta program ini untuk meningkatkan pengetahuan dan wawasan mereka secara otodidak. Selain pengetahuan bahasa Arab sebagai dasar untuk memahami al-Qur'an dan Hadits, Muhammad Basiuni Imran selalu menekankan pentingnya menguasai ilmu sejarah, geografi, psikologi, sosiologi dan politik. Ilmu-ilmu ini mutlak diperlukan untuk menunjang keberhasilan dakwah di tengah masyarakat yang semakin kompleks. ${ }^{62}$

\section{PENUTUP}

Berdasarkan pembahasan di atas dapat ditarik kesimpulan bahwa pemikiran pembaruan pendidikan Muhammad Basiuni Imran adalah memodernisasi kurikulum. Mengintegrasikan kurikulum agama dan kurikulum umum. Sejak Muhammad Basiuni Imran masih belajar di Mekah atau tepatnya saat ia pulang ke Sambas tahun 1906,

\footnotetext{
${ }^{59}$ Erwin Mahrus, Falsafah dan Gerakan Pendidikan Islam, h. 92.

${ }^{60}$ Erwin Mahrus, Falsafah dan Gerakan Pendidikan Islam, h. 92.

${ }^{61}$ Wawancara dengan Aminuddin Hardigaluh, murid di Kulliyatul Muballighin di Sambas.

${ }^{62}$ Erwin Mahrus, Falsafah dan Gerakan Pendidikan Islam, h. 95.
} 
pengaruh pembaruan pemikiran Islam sudah tampak kelihatan ketika ia berlangganan majalah al-Manār. Dampak majalah al-Manăr pada dirinya kelihatan saat ia menyampaikan khutbah yang isinya mengajak kepada masyarakat Sambas agar berupaya untuk sekolah, karena dengan pendidikan umat Islam bisa bangkit dari keterbelakangan. Sebagai seorang lulusan Mesir pada tahun 1913 yang pada waktu itu sedang berkembang pemikiran pembaruan yang dipelopori oleh Jamaluddin al-Afgani, Muhammad Abduh dan Rasyid Ridā setidaknya memberikan bekas kepada Muhammad Basiuni Imran. Pada tanggal 9 November tahun 1913 ia dilantik sebagai Maharaja Imam di kesultanan Sambas dengan besluit S.P. Tuanku Sultan Muhammad Syafiuddin, suatu gelar jabatan yang sangat strategis dalam mengembangkan pembaruan pemikiran. Pembaruan pemikiran pendidikan Islam mulai tampak ketika ia diserahi tugas untuk mengawasi sekolah agama yang dalam hal ini adalah Madrasah alSultaniyah pada tahun 1916. Pada posisi tersebut ia menawarkan beberapa mata pelajaran umum diajarkan juga dalam madrasah tersebut selain mata pelajaran agama. Pemikiran seperti ini belum terpikirkan oleh pemangku kebijakan pada saat itu. Alasan Muhmmad Basiuni Imran menawarkan ide tersebut tidak lain adalah agar umat Islam keluar dari kejumudan, kebodohan dan kemiskinan lantaran tidak berpendidikan. Salah satu pertanyaan yang disampaikannya kepada Rasyid Ridā selaku gurunya di Madrasah Dár al-Da'wah wa al-Irsyäd di Mesir adalah realitas umat Islam pada umumnya dan umat Islam Sambas khususnya. Terobosan ini berlangsung sampai Madrasah alSultaniyah ini ditutup oleh kolonial Belanda mengingat Belanda mengalami defisit keuangan akibat krisis ekonomi pada saat itu. Upaya pembaruan selanjutnya dalam aspek pendidikan Islam adalah mendirikan sekolah Tarbiyatul Islam sebagai pengganti dari Madrasah al-Sultaniyah. Sekolah ini berdiri pada tahun 1936 di Sambas hasil diskusi panjang dengan para guru muslim yang mengajar di sekolah umum milik Belanda. Sekolah Tarbiyatul Islam sudah menggabungkan kurikulum Barat dan kurikulum agama. Mata pelajaran yang diajarkan pada sekolah umum seperti ilmu alam, ilmu hewan, ilmu tumbuhan, ilmu manusia, ilmu sejarah, berhitung, bahasa Belanda dan menyanyi juga diajarkan pada sekolah ini. Selain itu Muhammad Basiuni Imran memperkenalkan sistem pendidikan ko-edukasi yaitu kesetaraan antara siswa laki-laki dan perempuan dalam pendidikan, sehingga siswa laki-laki dan perempuan dikumpulkan dalam satu kelas. Hal ini belum pernah terjadi sebelumnya bahkan sekolah katolik sekalipun memisahkan siswa laki-laki dan perempuan. Kemudian Muhammad Basiuni Imran juga memperkenalkan manajemen pendidikan berbasis admistrasi yang dimulai dari absensi siswa, evaluasi hasil belajar/raport sampai pemberian ijazah kepada siswa yang telah tamat belajar. Semangat ini tidak lain adalah kepeduliannya terhadap pendidikan umat Islam Sambas bahwa untuk melepaskan bangsa ini dari penjajahan dunia barat tidak lain dengan pendidikan sebagai hasil pembacaannya atas pemikiran-pemikiran Rasyid Ridha dalam majalah al-Manār yang menjadi langganan bacaannya. Sampai tahun 1963 Muhammad Basiuni Imran berpikiran visioner untuk mendirikan sekolah yang dijadikan sebagai persiapan pendirian Fakultas Ushuluddin di Sambas dengan nama Kulliyatul Muballigin. Pendirian Kulliyatul Muballigin dengan maksud agar anak muda pencinta ilmu tidak perlu jauh belajar sampai ke luar daerah karena sudah ada perguruan tinggi. Namun upaya ini belum terwujud lantaran banyak faktor pengambat. Pendirian Madrasah alSultaniyah, Sekolah Tarbiyatul Islam maupun Kulliyatul Muballigin adalah dalam rangka mencerdaskan kehidupan bangsa dengan harapan usaha tersebut tidak terhenti pada masanya namun berlanjut pada murid-muridnya agar meneruskan pendidikan dengan mendirikan sekolah-sekolah di tempat asal muridnya. Dengan demikian tampak bahwa Muhammad Basiuni berhasil melalukan pembaruan dalam pendidikan Islam dengan model perubahan sosial evolutif bertahap. Melakukan perubahan tidak serta merta tapi sebagai akibat dari akumulasi pendidikan masa sebelumnya dari yang sederhana sampai pada tahap yang dikembangkan oleh Muhammad Basiuni Imran. 


\section{DAFTAR PUSTAKA}

Abaza, Mona. Indonesian Student In Cairo. Paris: Association Archipel, 1994.

Abdurrahman, Dudung. Metodologi Penelitian Sejarah. Yogyakarta: Ar-Ruzz Media Group, 2007.

Ahok, Pasifikus. Sejarah Pendidikan Daerah Kalimantan Barat. Pontianak: Depdikbud, 1983.

Al-Attas, Syed Muhammad Naquib. Islam Dalam Sejarah dan Kebudayaan Melayu. Bandung: Penerbit Mizan, 1990.

Arselān, Amīir Syakīb. Limāzā Taākhara al-Muslimūn wa Limāżā Taqaddama Ghairuhum. Lebanon: Mansyurat Dar al-Maktabah al-Hayah, t.t.

Asry, M. Yusuf. ed, Profil Paham dan Gerakan Keagamaan. Jakarta: CV Prasasti, 2009.

Azra, Azyumardi. Jaringan Ulama Timur Tengah dan Kepulauan Nusantara Abad XVII dan XVIII. Bandung: Mizan, 1995.

. Pendidikan Islam: tradisi dan Modernisasi Menuju Milenium Baru. Jakarta: Logos, 1999.

. "Tradisi Politik", dalam Taufik Abdullah et al., (ed), Ensiklopedi Tematis Dunia Islam, Jilid 5. Jakarta: Ichtiar Baru Van Hoeve, 2002.

Black, Antony. The Historical Of Islamic Political Thought From the Prophet to the Present. New York: Edinburgh University Press, 2001.

Bruinessen, Martin Van. Kitab Kuning; Pesantren dan Tarekat; Tradisi-Tradisi Islam di Indonesia. Bandung: Mizan, 1999.

Effendy, Machrus. Riwayat Hidup Dan Perjuangan Maharaja Imam Sambas. Jakarta: Dian Kemilau, 1995.

Fahmi, Urai Reza. Selayang pandang Kerajaan Islam Sambas. Sambas: Istana Alwatzikhoebillah Sambas, 2008.

Gazalba, Sidi. Pengantar Sejarah Sebagai Ilmu. Jakarta: Bhratara Karya Aksara, 1981. Masjid Pusat Ibadat dan Kebudayaan Islam. Jakarta: Pustaka Antara, 1983.

Horgronje, Snouck. Verspreide Geschriften, Deel V, Eerste Reeks. Bonn Und Leipzig, 1924.

Islam di Hindia Belanda. Terj. S. Gunawan. Jakarta: Bhratara Karya Aksara, 1983.

Imran, Muhammad Basiuni. Cahaya Suluh. Singapura Matba'ah al-Ikhwan, 1920.

. Sabīil al-Najāh Ilā Tadzkīr Tarik al-Shalāh. Singapura: Matba'ah Ahmadiyah, 1931.

Khulāshah al-Sïrah al-Muhammadiyah. Singapura: Matba'ah Ahmadiyah, 1932.

. Bidayāh al-Tauhīd Fì 'Ilm al-Tauhīd. Singapura: Matba'ah Ahmadiyah, 1934. 
Irsyād al-Ghilman Ilā Adabi Tilāwah al-Qur'ān. Singapura: Matba'ah, 1934.

Durūs, al-Tauhid; al-Sayyid Muhmmad Rasyid Ridha. Singapura: Matba'ah Ahmadiyah, 1935.

. Nür Siraj Fì Qishshah al-Isrā' Wa al-Mi'rāj. Singapura: Matba'ah Ahmadiyah, 1938.

. Al-Janāiz. Tasik Malaya: Galunggung, 1943.

. Daftar Sedjarah Perdjalanan Hidup dari Hadji Mohamad Basioni Imran: Maharaja Imam Sambas. Naskah: 13 Juni 1950.

. "Mas'alah Ichlas", Naskah. Kulliyatul Muballighin, 1967.

Kartodirjo, Sartono. Pengantar Sejarah Indonesia Baru: 1500-1900 Dari Emporium Sampai Imperium. Jakarta: Gramedia Pustaka Utama, 1999.

Kesuma, Pangeran Tumenggung Jaya. Laporan Tentang Kontrak dan Riwayat RajaRaja Sambas. Sambas: Naskah, 1951.

Koentjaraningrat. Pengantar Ilmu Antropologi. Jakarta: Rineka Cipta, 2009.

Khoiriyah. Islam dan Logika Modern, Mengupas Pemahaman Pembaruan Islam. Yogyakarta: Ar-Ruzz Media Group, 2008.

Kuntowijoyo. Pengantar Ilmu Sejarah. Yogyakarta: Yayasan Bentang Budaya, 2001.

Metodologi Sejarah. Yogyakarta: Tiara Wacana, 2003.

Mahrus, Erwin. Membangun Pendidikan ; Gagasan Pendidikan Maharaja Imam Sambas Basiuni Imran 1885-1976. Pontianak: Yayasan Leluhur Nusantara, 2003.

Syeikh Ahmad Khatib Sambas; Sufi dan Ulama Dikenal Dunia. Pontianak: Untan Press, 2003.

Falsafah Dan Gerakan Pendidikan Islam, Maharaja Imam Sambas Muhammad Basiuni Imran ( 1885 - 1976 ). Pontianak: STAIN Pontianak Press, 2007.

Maksum. Madrasah, Sejarah dan Perkembangannya. Jakarta: Logos, Penerbit Wacana Ilmu, 1999.

Mughni, Syafiq A. Hassan Bandung Pemikiran Islam Radikal. Surabaya: Bina Ilmu, 1994.

Mustafa, H. A. Sejarah Pendidikan Islam di Indonesia. Bandung: CV. Pustaka Setia, 1998.

Nata, Abudin. Sejarah Pendidikan Islam Pada klasik dan Pertengahan. Jakarta: Raja Grafindo, 2001.

. Metodologi Studi Islam. Jakarta: Raja Grafindo, 2001.

Noer, Deliar. Gerakan Modern Islam Di Indonesia 1900 - 1942. Jakarta: LP3ES, 1996.

Pijper, G. F. Beberapa Studi Tentang Sejarah Islam di Indonesia 1900-1950. Terjemahan Tudjimah dan Yessy Augusdin. Jakarta: UI Press, 1985.

Pranoto W, Suhartono. Teori dan Metodologi Sejarah. Yogyakarta: Graha Ilmu, 2010. 
Rahman, Ansar. Kabupaten Sambas; Sejarah Kesultanan dan Pemerintahan Daerah. Sambas: Dinas Pariwisata Pemkab Sambas, 2001.

Rahmat. Pengantar Ilmu Sejarah. Makassar: Alauddin University Press, 2012.

Mawardi Riva'i, “Peranan Sultan Tengah”, Makalah. Pontianak: Balai Kajian Sejarah dan Nilai Tradisional, 1986.

Risa. Perkembangan Islam di Kesultanan Sambas; Kajian Atas Lembaga Keislaman Pada Masa Pemerintahan Sultan Muhammad Syafiuddin II Tahun 1866-1922 M. Yogyakarta: Ombak, 2016.

Salim, Mohd. Haitami dkk. "Haji Muhammad Basiuni Imran Maharaja Imam Sambas (Studi Tekstual Latar Belakang Pendidikan, Kegiatan dan Penghargaannya)", Laporan Penelitian. Pontianak: Fakultas Tarbiyah IAIN Syarif Hidayatullah, 1998.

Shadily, Hassan. Sosiologi Untuk Masyarakat Indonesia. Jakarta: Bina Aksara, 1983.

Statuten (AD/ART) Perkoempoelan Tarbiatoel Islam, 1936.

Sunandar. Peran Maharaja Imam Muhammad Basiuni Imran dalam Kehidupan Sosial Keagamaan Masyarakat Kerajaan Al-Watzkhoebillah Sambas 1913-1976. Tesis, Yogyakarta: Pascasarjana Konsentrasi Agama dan Filsafat, UIN Sunan Kalijaga, 2012.

Tilaar, H.A.R. 50 Tahun pembangunan Pendidikan Nasional 1954-1995, Suatu Analisis Kebijakan. Jakarta: Gramedia, 1995.

Yatim, Badri. Historiografi Islam. Jakarta: Logos Wacana Ilmu, 1997.

Yunus, Mahmud. Sejarah Pendidikan Islam di Indonesia. Jakarta: Mutiara Sumber Widya, 1995. 